\title{
Landscape Perception in Peri-Urban Areas: an Expert-Based Methodological Approach
}

\begin{abstract}
While there is general consensus on the importance of landscape perception in urban studies, there is still a need to broaden the toolkit for researchers and practitioners to document, analyse and interpret these inputs, in line with the postulates of the European Landscape Convention and overcoming conventional formats based on descriptions and static photography. This becomes particularly pertinent in the peri-urban landscapes of large cities, bearers of the relations and contradictions between urban growth, resource consumption and landscape protection, and especially vulnerable to tabula rasa approaches. We case study the surrounding landscapes of Madrid at a metropolitan scale, addressing the gap between scopes and scales of recent landscape reports and focusing on two elements connecting (visually, or physically) the city with its commuting zone: lookouts and roads. An expert-based methodology presents the criteria for their selection and a description of desk and field work. A sample for each local approach is further developed to exemplify the application, combining cartography, 3D modelling, visual basins, on-site photography and interpretive drawings. This results in a multifaceted vision of how the city and its hinterland is perceived, illustrating both outstanding and everyday landscapes and how they interweave in a continuous experience.
\end{abstract}

Eva J. Rodríguez Romero, Carlota Sáenz de Tejada Granados*, Rocío Santo-Tomás Muro

Universidad CEU San Pablo, Department of Architecture and Design, Montepríncipe Campus, Madrid; Spain

\footnotetext{
*Corresponding author: Carlota Sáenz de Tejada Granados, Universidad CEU San Pablo, Department of Architecture and Design, Montepríncipe Campus, Boadilla del Monte; 28668; Madrid; Spain; car.saenzdetejada@ceindo. ceu.es
}

\section{Keywords:}

Landscape Perception, Peri-Urban Landscape, Visualization Tools, Lookouts, Roads. 


\section{Introduction}

\subsection{Motivation and goals of the study}

The current framework for landscape valorisation, greatly fostered by the postulates of the European Landscape Convention (Council of Europe 2000), has led to a growing sensibility towards the less tangible facets of landscape experience (Jones, Patterson \& Hammitt 2000, Antrop 2005, Davenport \& Anderson 2005, Jones et al. 2017). Due to the combination of its physical features, cultural charge and the aspirational subtleties it sparks in the communities, landscape is considered to have a direct impact on the quality of life of those who experience it, therefore becoming a decisive tool for its design (Zárate 2011).

General consensus has been reached on the importance of human perception in landscape studies (Zube \& Pitt 1981, Daniel 2001, Ode et al. 2009, Jones \& Evans 2012). However, there is still a pressing need to broaden the toolkit for urban designers, landscape architects and geographers to capture, document, analyse and interpret these inputs, translating them into assets for the management of both landscape preservation and change (Coles et al. 2013). Data on landscape perception at a local scale feeds into the identification and character assessment of landscape units at a broader scale (Tudor, 2014), merging tangible and intangible elements, equally crucial to understand how landscapes are valued by their communities.

Peri-urban landscapes are, by definition, less consolidated areas where urban and rural land uses converge. Urban development, by far the most rapidly expanding land use change in Europe (Piorr et al. 2011), poses a risk for the negative dynamics of urban sprawl to arise, as well as constitutes and opportunity for economic development. The complex reality of these areas of influence around large cities calls for a closer look at the basic landscape elements that conform them, and that link, both visually and physically, the city with its daily communing zone.

This work seeks to assess the pertinence of main access roads and natural lookouts as instruments to tackle the issue of landscape perception in large cities. We present an expert-based methodology for landscape documentation, analysis and interpretation, intended to be highly flexible and adaptable to a wide range of case studies. The proposed method, entailing both deskwork and fieldwork, brings together a series of different tools and formats in a systematic manner, combining cartography analysis, 3D modelling, generation of visual basins, on-site photography and interpretive drawings in an aim to transcend conventional formats of displaying and analysing 'perceptive data', which in expert-based methods is often relegated to mere descriptions and static photography (e.g. see Sanz Herráiz \& Mata Olmo 2010).

As a proof of concept and example of its implementation, we case study Madrid; a European capital with a highly densified metropolitan area. In this region, few landscape reports of different scale and scope have left both a physical and conceptual gap of knowledge in terms of the city's peri-urban area. A brief overview of recent dynamics in its surrounding landscape precede the proposed methodology, where we present the criteria for the selection of the landscape elements of study (lookouts and roads), followed by a description of desk and field work. Samples of each local approach are further developed to exemplify the application of the method.

\subsection{The (neglected?) peri-urban landscape}

One of the main characteristics of the twentieth century has been the fast urbanization process, based on an important population growth, especially remarkable in South-West Europe (Chatel et al. 2017). However, the speed, frequency and magnitude of landscape change has increased particularly in the second half of the twentieth century. This has made the identification and study of its main driving forces an imperative matter in recent years (Antrop 2005), driving new attention towards the areas of influence around cities and increasing awareness of the potential negative effects of 'urban sprawl' (Allen 2003, Qviström \& Saltzman 2006, Berger 2006).

Peri-urban areas in Europe are predicted to have a leading role in the near future, doubling in the next 30-to-50 years: a much faster growth rate than urban areas (Piorr et al. 2011). In addition to urban population growth and rural exodus, an outward 
spread of urban activities to the surrounding hinterland results in an important increase of artificial land around the urban core, strongly structured by growing transportation networks and vulnerable to governance gaps, landscape fragmentation and an overall lack of identity (Simms et al. 2005).

The peri-urban interface has traditionally been conceived from a dichotomous perspective (Allen et al. 1999); areas lacking 'urban' attributes (such as higher population density, accessibility, services or infrastructure), while also lacking the 'naturalness' or soil fertility associated to the 'rural' realm. This distinction, strongly rooted in traditional planning systems (Qviström 2010), has proven insufficient to effectively qualify peri-urban areas, and inadequate to tackle environmental and urban development processes in these contexts (Allen 2003).

As socio-economic systems (Eurostat 2016), or heterogeneous mosaics of natural, productive and urban ecosystems (Allen 2003), peri-urban areas are a field for the study of rural-urban flows and interactions with the potential to become operational in future strategies for protection, management and development (Palang et al. 2011). However, quite surprisingly given their abundance and growing importance, we find very few experiences of aesthetic valorisation in peri-urban landscapes (Serrano Giné 2015, 2018).

\subsection{The role of perception in Landscape Character Assessment (LCA)}

Though there are some commonly recognized features of the landscape, 'what we perceive as the environment is in fact a synthesis in which our current perceptions of what is actually out there are combined with a complex tapestry of associations based on our experience, both of the physical world and of other people' (Greenbie 1982).

Since the major impetus for systemic analysis and studies of landscape beauty, amenity and preference during the 1960s and 1970s (Zube et al., 1982, Appleton 1975, Kaplan \& Kaplan 1978, Cullen 1971), concepts such as 'sense of place' (Jones \& Evans 2012), 'place attachment' and 'identity' (WesterHerber 2004, Devine-Wright 2013), or the myth of rural idyll (van der Horst \& Lozada-Ellison 2010) have been explored from different perspectives, especially in relation to land-use conflicts. Indeed, perception plays a key role in landscape definition and valorisation. Landscape Character Assessment (LCA) provides a useful method to tackle the complexity of landscape which, due to its dynamic nature, calls for an integrated approach to its study, based upon holism, perception and evolution (Antrop 2000).

LCA involves an understanding of how the landscape is perceived and experienced by people (Tudor 2014), and does so by combining factual statements with more subjective and evocative elements, which together generate the character of a place. From colour, texture, patterns and forms; to sounds, smells, associations and memories. These symbolic and aesthetic factors, largely ascertained through field work, are considered and incorporated to the collection of data.

Therefore, whether directly linked to controversial issues of project siting, landscape justice, or to landscape change in general, a deeper understanding of the mechanisms of perception has proven essential to uncover certain aspects, often hidden or disregarded, of how landscape is experienced. In this sense, there is a growing need to come up with tools for researchers and practitioners to effectively detect, represent and analyse 'perceptive data' (Jones \& Evans 2012).

\subsection{Outstanding and everyday landscapes}

'Even the simplest, least interesting landscape often contains elements which we are quite unable to explain, mysteries that fit into no known pattern. But we also eventually learn that every landscape, no matter how exotic, also contains elements which we at once recognize and understand' (Jackson 1984).

In the continuous sequence in which we experience our environment, the 'moving gaze' as described by Sheller and Urry (2006), outstanding and everyday landscapes are constantly interwoven. Art.2 of the European Landscape Convention refers to the wide range of landscapes that should be accounted for, acknowledging the importance of both 'outstanding' and 'everyday' landscapes and their worthiness to be studied. However, inevitably some landscape 
types have received much more attention that others throughout history. For instance, while lookouts are generally linked to more aesthetically pleasing views, the roads are often considered to provide the less appealing facet of the city. The work here presented builds on this (false?) dichotomy to offer documentation and analysis of the landscapes provided by a selection of natural lookouts and main access roads in the peri-urban realm of Madrid.

\section{Lookouts}

As silent witnesses of the evolution of its surrounding landscape, lookouts have always had the potential to provide vast, recognizable panoramas (for the case of Madrid, see Rodríguez Romero \& Sáenz de Tejada Granados 2016). The views depicted from certain lookouts by painters throughout history have made for iconic images today, part of the collective imagery of a place and charged with symbolism. The 'urban cosmography' that these images of a city embody show that their interest extends beyond their geographical content (Kargon 2014). For instance, the chorographies by Anton van den Wyngaerde, commissioned by Philip II of Spain in the sixteenth century, would not only serve as documents representing the state of certain Spanish cities at the time, but often served as a means to express pride, patriotism or suzerainty (Kagan 1986). The most iconic image of Madrid in the eighteenth century, the south-western view of the 'cornice', was depicted by Francisco de Goya in 1788 from a natural lookout that, still today and despite extensive growth and transformation of the city, represents an important site from where the 'older' city can be contemplated (Fig. 1).

Some cities have established legal frameworks for the protection of their most relevant views. Such is the case of Edinburgh, where the Skyline Report (Planning Committee of Edinburgh 2008) identifies views that are essential in defining the image of the city and establishes guidance for their protection in future developments. The city of Vancouver has also come up with a protection guidance in this line, chiefly concerning the height of new buildings not affecting the 'view cones' of the most relevant scenes, including views from its shoreline and bridges (City Council of Vancouver 2011). Pelli-Cajasol tower in Seville, built in 2015, could constitute a counter- example in this regard, for its scale and architectural language has been considered to denature the city's skyline, undermining the traditional landmarks and other landscape references (Negussie \& Fernández 2013). Madrid, case study for this work, has not yet implemented specific regulation in this sense, though public debate often raises around the protection of emblematic views, especially in the face of new projects; such was the case of the Partial Plan for the internal renovation of the cornice of River Manzanares (Las Vistillas) of 2009, where plans to incorporate new buildings to the iconic landscape ensemble were done in detriment of potential muchneeded green area (Zárate 2011).

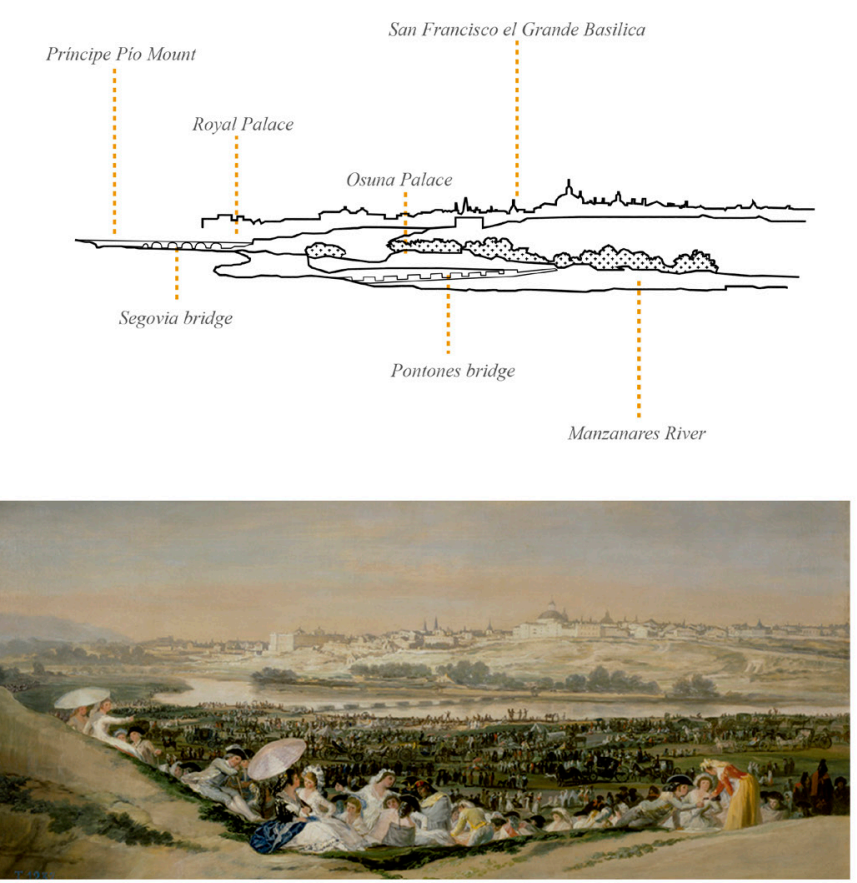

'La Pradera de San Isidro' by Francisco de Goya, 1788

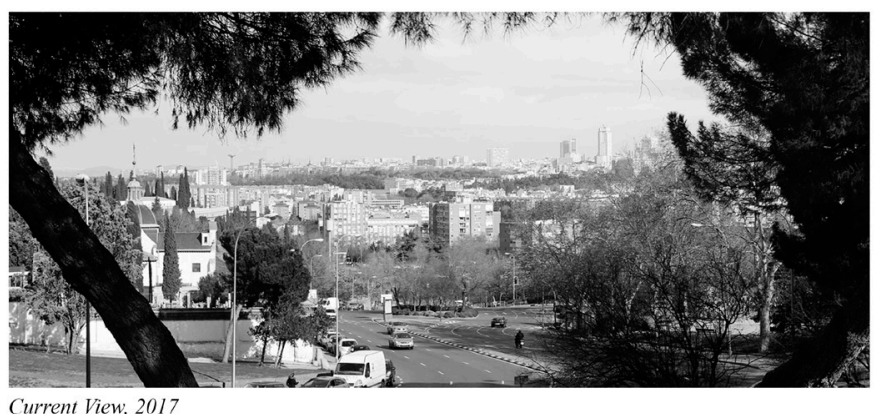

Figure 1: Interpretive drawing and current view from the natural lookout chosen by Francisco de Goya to depict Madrid in the eighteenth century. 
In Madrid, as in the case of other European cities where specific regulation concerning the protection and management of views is not yet established, the conjunction of urban planning and heritage policies today falls short of the attention and protection the complex landscapes of a city and its hinterland require.

\section{Roads}

The growth and sprawl of our cities has inevitably led to the revision of the act of walking as the only valid practice to experience a city. Revisiting Michel de Certeau's concept of walking as an everyday 'furtive' practice of appropriation of the city by the people (de Certeau 1980), one could wonder if de Certeau's concept of the city fits into today's oversized and complex urban and peri-urban fabrics, which have 'engulfed' the automotive boom and are often structured based on its requirements. As Nigel Thrift (2004) would point out, the determining role that driving has had in the growth and transformation of our cities and peripheries has made this everyday action worthy of study and attention, for the experience of driving through the landscape can be, in many ways, as revealing as walking through it. In this sense, attention to how motor roads have shaped our experience of space and place has been extensively covered as part of our vernacular landscapes (Jackson 1984, 2011), and is present in recent research in social science (Merriman 2008, 2009), as well as explored from artistic approaches (Martí 2014).

However, under the premise of urbanization and its associated infrastructures 'impacting' on the tranquillity and quality of life provided by 'natural' landscapes, roads have traditionally been considered to offer the views with less quality, especially in those sections within the commuting zone. For instance, for the generation of Simon Rendel's Tranquility Maps of England in the early 1990s, highways and their associated traffic flows (along with other 'noisy' or 'visually disturbing' elements and uses such as industrial infrastructures or major urban centres) were considered to have a negative impact on the desired 'calmness and enjoyment of nature', directly linked to the quality of life of the communities.
Conversely, in the context of the American counterculture of the 1960s, perhaps more 'experimental' works throughout the next years brought fresh perspectives to urban landscape perception from the road, while also addressing issues of urban sprawl, architectural paradigm shift, or symbolism. This was done in cities such as Los Angeles (Hopper 1961, Banham 1971), Las Vegas (Venturi et al. 1977), or in the suburbs of New York with Tony Smith's 'revealing experience' while driving the New Jersey Turnpike (Wagstaff 1966) and Robert Smithson's works on its industrial 'monuments' (Smithson 1967).

Half-way between these two conceptual approaches towards the road-landscape relationship could be the creation and preservation of scenic roads, promoting the 'driving for pleasure' experience through emblematic landscapes, usually with high environmental quality (in this sense, the efforts put in countries such as the United States of America, Japan, or Norway are worth mentioning). These scenic drives are generally provided with alternative high-capacity itineraries, lessening the traffic flow in order to ensure a more enjoyable experience, where the landscape values passed by can be fully grasped.

Perhaps the biggest challenge today, however, is attending to those landscapes prone to abandonment and degradation which often align along those roads that have no intention of becoming 'scenic drives', but which nevertheless are the daily scenery for a great number of people. Such is the case of the 'access roads' to the city centre, which strongly structure the peri-urban space and constitute the main flux channels of people and resources between the urban core and its surrounding territory. The frequency with which these views are perceived, with a high number of probable observers, make the views from these roads especially fragile and vulnerable (Español Echániz 2010). Nevertheless, in the views from these roads lies great potential to improve the daily experience of said people. 


\section{Case study: Madrid}

\subsection{Recent dynamics in the peri-urban fringe of Madrid}

Madrid is the third largest Functional Urban Area of the EU-28 (OECD Territorial Development Policy Committee 2013), with a total population of over 7 million as to 2014, after London and Paris with 12.4 and 13 million each. It holds, however, one of the highest sprawl indices for the 2000-2012 period, meaning it is no stranger to the effects of a disproportionate increase of artificial land respect to urban population growth. This trend of the last decades has led to an increasing proximity of urban land use (and its associated infrastructure) to areas of high ecological and scenic value, specifically Natura 2000 sites (Gallardo \& Martínez-Vega 2016), illustrating how peri-urban landscapes are often bearers of the relations and contradictions between urban growth, resource consumption and landscape protection.

The consolidation of the metropolitan area of Madrid in the 1970s was a consequence of a national shift of paradigm in terms of the migrating trend of previous years; the destination of newcomers from abroad or from rural areas was no longer the great cities, but rather the neighbouring municipalities, close to the centres of activity but avoiding the cost, both economical and of quality of life, imposed by the high population density of the urban core (Azagra et al. 2006). This led to the shaping of a dense network of outlaying cores around Madrid, which today holds significantly higher population densities (at up to 30 kilometres from the city centre) than those of any other European capital (United Nations General Assembly 2016). Such densified hinterland becomes the focus of this research.

The metropolitan region around Madrid has been defined by regional institutions for statistical purposes (Spanish Statistical Office 2017), however this concept (or scale of understanding of the 'real' city) is not present in urban or landscape plans and reports, usually limited to administration boundaries; yet again creating governance gaps that can easily result in spatial fragmentation and lack of attention towards the city at a metropolitan scale (Allen 2003). Furthermore, strategic reports often lack a binding nature, relegating them to a series of recommendations that not always come through in urban developments.

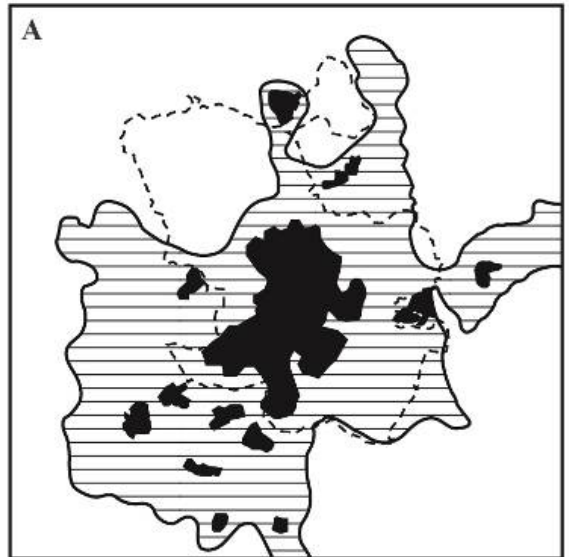

--. city centre administration boundary

city cores

large city's metropolitan area

\section{(1)}

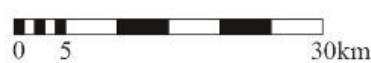

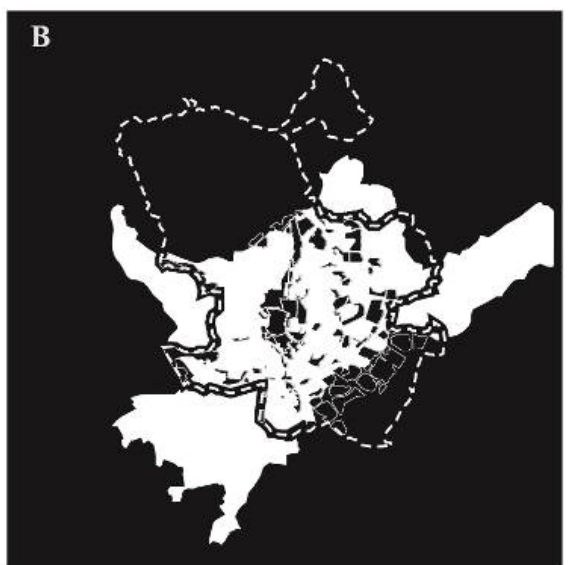

--- city centre administration boundary

areas defined in recent regional landscape reports

areas not covered by recent regional landscape reports

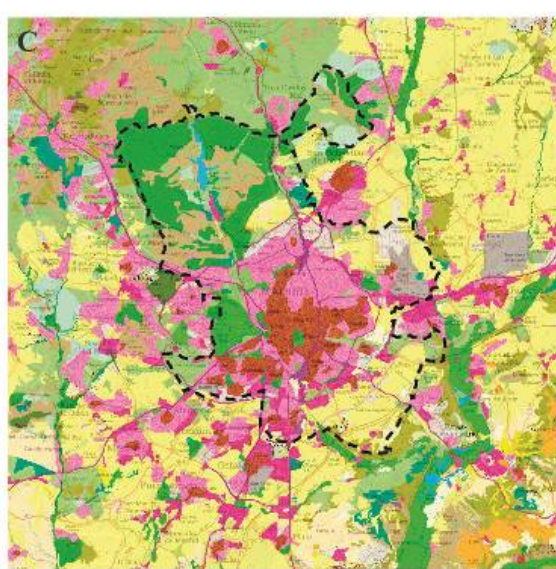

- - city centre administration boundary

continuous urban fabric

discontinuous urban fabric

industrial/commercial areas

forests, green and irrigated land non-irrigated arable land

road \& rail networks and associated land

Figure 2: Previous landscape studies and land use cover for Madrid and its surroundings (A: Atlas of Spanish Landscapes, 2010; B: overlapping of areas covered in urban landscape report by Madrid's city Council in 2009 and in the natural landscape report by the Autonomous Community of Madrid, 2007; C: land use cover, 2000). 


\subsection{Previous approaches towards the definition and qualification of its peri-urban area}

The first approach to a landscape characterization of the entire territory of Spain was carried out by Sanz Herráiz and Mata Olmo (2010) with the purpose of creating a nation-wise continuous map of landscape types and units, descending at times to a regional scale, however focusing mainly on natural features and outlining the large cities and metropolitan areas (Fig. 2A). This effort to apply a systematic method of landscape characterization throughout the country has served as a useful starting point for regional institutions (Generalitat Valenciana, Xunta de Galicia or Junta de Andalucía, among others) willing to incorporate the 'landscape variant' to territorial and urban decision-making to carry out studies at a closer scale.

In the region of Madrid, two landscape reports have stemmed from this context: the Environmental Study of the Autonomous Community of Madrid (Environment and Territorial Planning Department 2007), and Madrid's City Council Plan for the Quality of Urban Landscape (Urban Planning and Housing Area 2009). While the first focuses upon the natural landscape of the autonomous community, the second studies the urban landscape within the city-centre limits, defining units according mainly to building typology and period of construction. Both, however, fail to address the transitional fringe between city and countryside (Fig. 2B); an area where the clash between administration boundaries and land uses has left a gap of knowledge, which becomes the main area of interest for this research.

\section{Methodology: local views within a metropolitan context}

As stated above, both natural lookouts and main access roads are considered to play a decisive role in the perception of the city and its surroundings for a significant amount of population, often on a daily basis. Figure 3 shows the selection of lookouts and roads for this case study; a total of fifteen natural lookouts and six main access roads. As a previous framework to their study, a historical cartography analysis of the city was developed (Rodríguez
Romero \& Sáenz de Tejada Granados 2016) from a metropolitan scale $(1: 750,000)$ to an urban scale $(1: 50,000)$, showing the most relevant stages of growth and transformation of the city from the 19th century to the present.

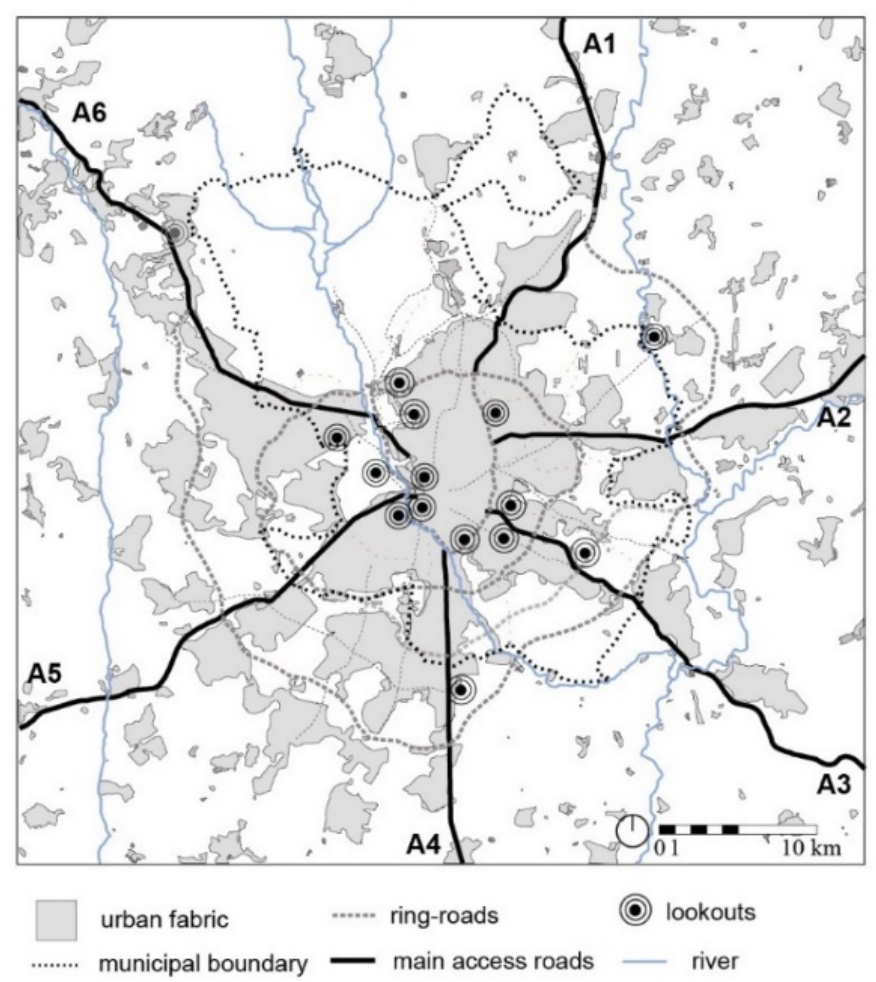

Figure 3: Metropolitan area of Madrid, showing the selection of lookouts and roads studied.

Descending to a local scale entailed both field and desk work. The field work was carried out between the months of February and June, therefore the data collected would correspond to the end of winter and spring seasons. Generally, sunny or partially cloudy days were deemed suitable for field trips, avoiding circumstances of low visibility, such as fog or heavy rain. Madrid benefits from these weather conditions approximately $80 \%$ of the days of the year (according to the Spanish Meteorological State Agency), which makes documenting landscape in these conditions highly representative.

\subsection{Lookouts: natural, public and accessible}

A selection of geographical points of high altitude is made from a 3D digital model of the area of study, generated using data from the National Geographic Institute (NGI 2017), exported to GlobalMapper 
software. The criteria for the selection of lookouts was aimed to achieve a relatively homogeneous sample around the urban fringe, with high visibility and large number of viewers:

- Minimum altitude of $630 \mathrm{~m}$

- Location within the peri-urban area of the city

- Visibility of the city's urban contour

- Accessible locations by foot

- Lookouts located in public spaces, free to access

The application of this selection criteria resulted in a sample of 15 lookouts, between 1.2 and $27 \mathrm{~km}$ from the city centre. In terms of altitude, the highest point is $844 \mathrm{~m}$ over sea level (Torrelodones), while the lowest is $630.7 \mathrm{~m}$ (San Isidro).

Once the selection of the lookouts is made, by means of GIS and a raster data model, a 360ㅇ viewshed analysis is carried out from these points to determine their visual basins. A map of those areas not obstructed by topography is generated, therefore showing what areas are potentially visible from that specific lookout (Fig. 4). The viewshed analysis consisted of a horizontal scanning of a $40 \mathrm{~km}$ radius from a height of $1.70 \mathrm{~m}$ above the ground.
However, the fieldwork following this mapping for each lookout proved to be fundamental in assessing the validity of these potential visual basins, for certain elements of the 'real' scenery (such as buildings, vegetation, street signs or lighting) affect the range of view.

The visual basins generated from the topographic model are compared with 360 - panoramas from each site. The panoramas were carried out by means of a sequence of photographs taken with a digital reflex camera (Canon EOS 5D Mark III), and then merged together as a continuous strip with graphic design software (Adobe Photoshop CC). On-site notes and sketches were taken, reflecting those elements considered (from the researchers' perspective) key in that particular place. Field work also allowed for a more accurate pinpointing of the lookouts' coordinates, for often the highest topographical point in the digital model is not the exact point from where the views open. These corrections over the previous coordinates are later reflected in the working documents.

The panoramas for each lookout are then analysed and interpreted, selecting the most relevant frames within the 360 o views (Fig. 5). Relevance is based on the ability of that frame to reveal the urban contour of the city and show historically significant landmarks and ensembles. These selected frames are further

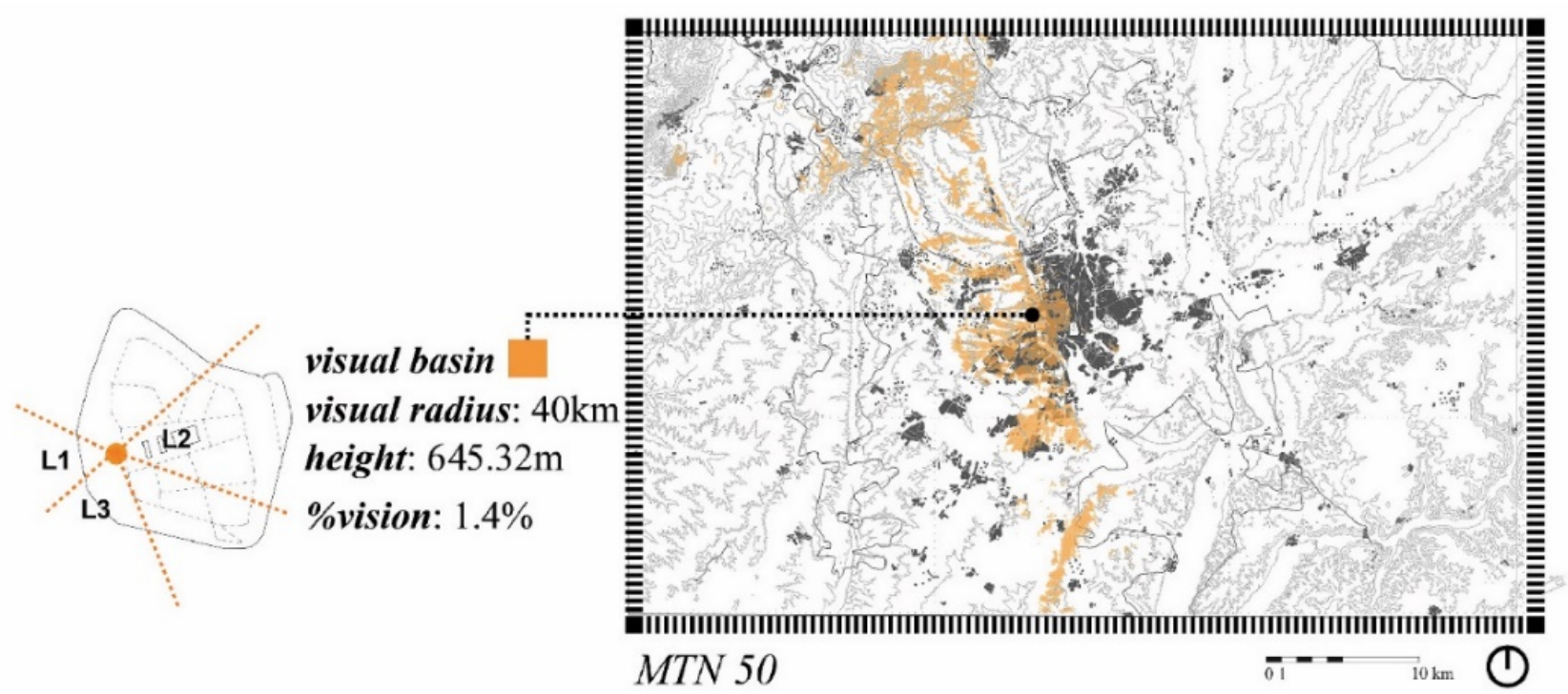

Figure 4: Potentially visible areas from 'Temple of Debod' lookout. 


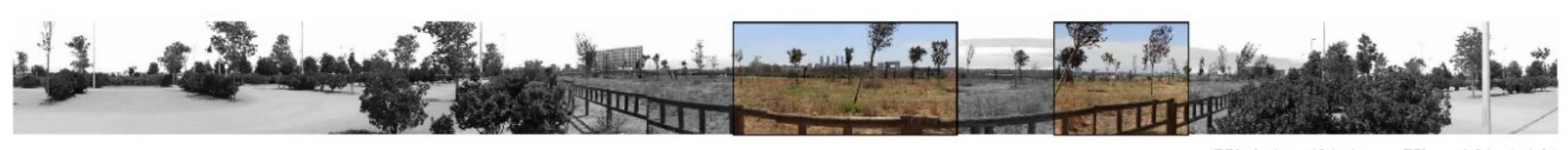

--- Parque Felipe VI ---

Hieight: $691.6 \mathrm{~m} \quad$ Visual \%: $1.6 \%$

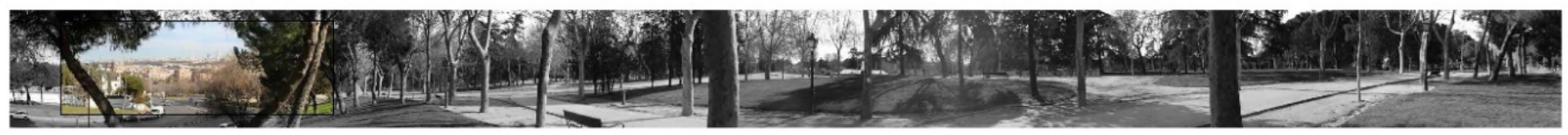

--- San Isidro ---

Hieight: $630.7 \mathrm{~m}$ Visual $\%: 2.5 \%$

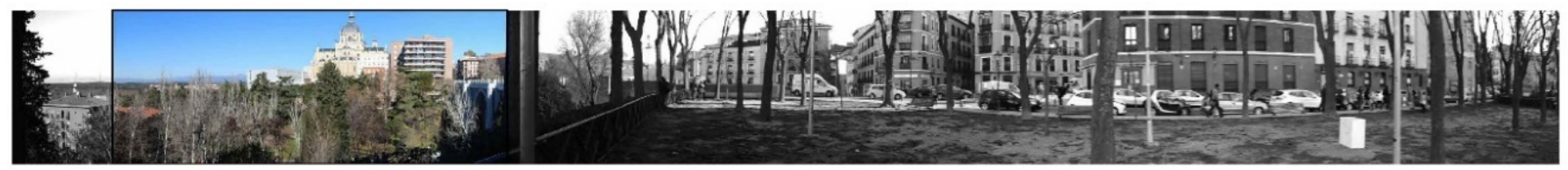

--- Las Vistillas ---

Hieight: $629.78 \mathrm{~m}$ Visual $\%: 2.3 \%$

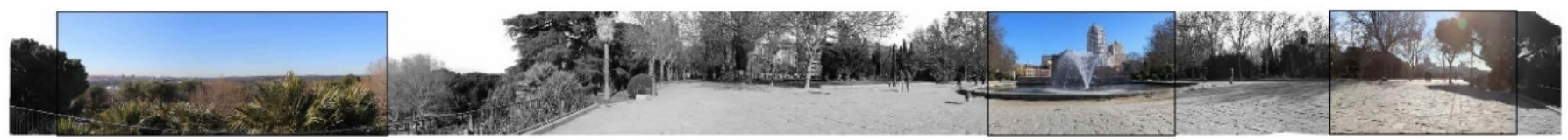

--- Templo de Debod ---

Hieight: $645.32 \mathrm{~m} \quad$ Visual \%: $3.2 \%$

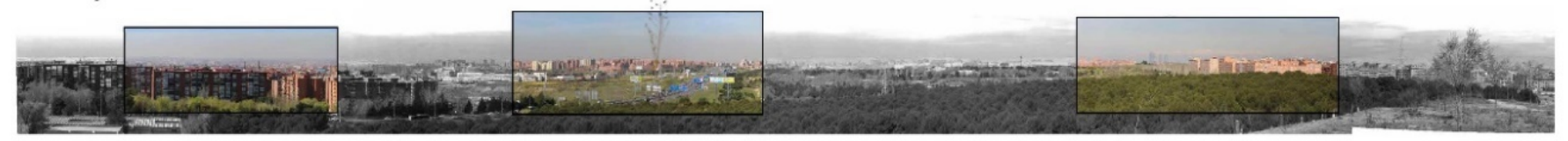

--- Parque del cerro del Tío Pío ---

Hieight: $680.6 \mathrm{~m} \quad$ Visual $\%: 4.8 \%$

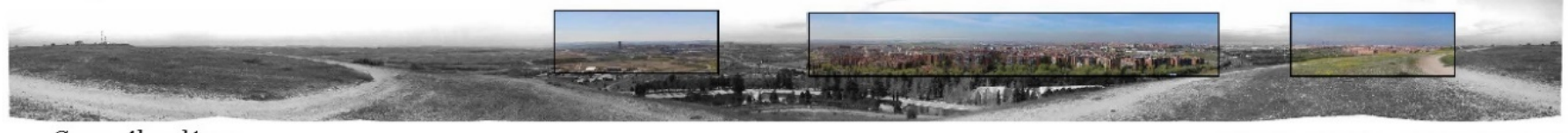

--- Cerro Almodóvar ---

Hieight: $722.9 \mathrm{~m}$ Visual \%: $14.3 \%$

Figure 5: Examples of 360 panoramas taken during fieldwork, showing the selection of the most relevant frames in each one for their further analysis.

analysed with interpretive drawings that introduce new layers of information to the view, for instance distinguishing between evergreen and deciduous vegetation, types of soil, identifying landscape elements such as barriers and landmarks, etc. all of which can aid in the assessment of a landscape character for that area (Fig. 6).
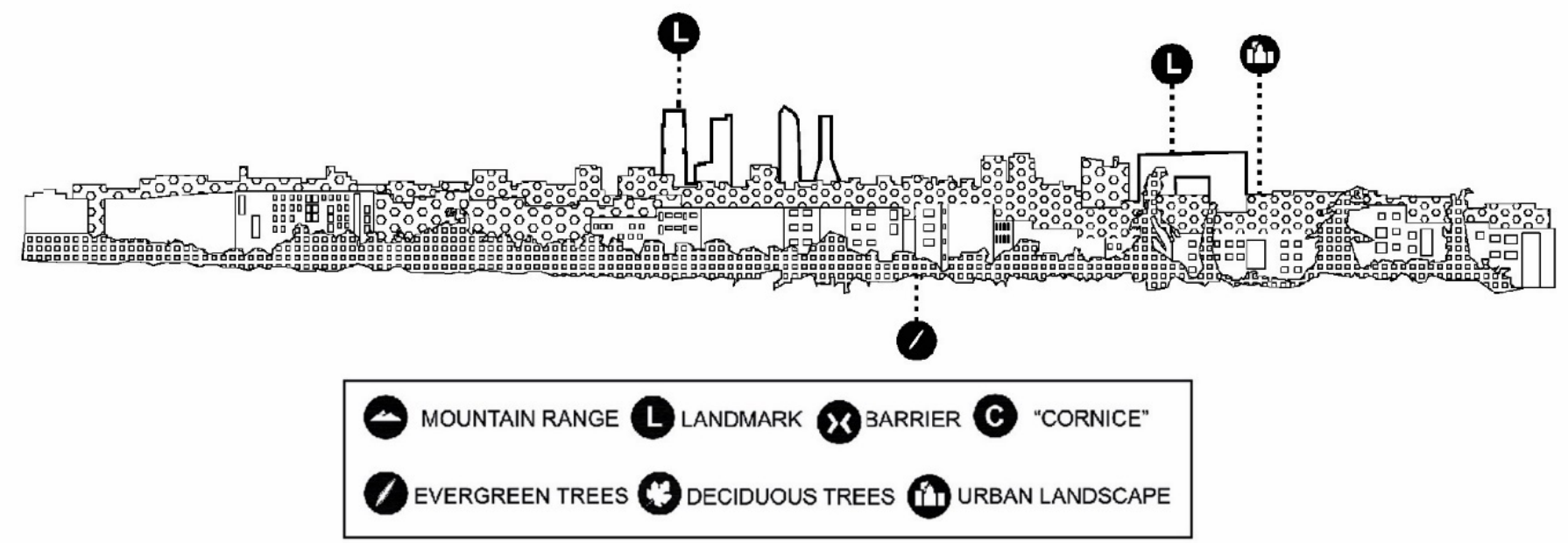

Figure 6: Interpretive drawing of the view from Felipe IV Park lookout. 


\subsection{Main access roads: framing the inbound view towards the city}

The six main roads leading to the city centre $(A 1, A 2$, $\mathrm{A} 3, \mathrm{~A} 4, \mathrm{~A} 5$ and $\mathrm{A} 6$ ) are arranged radially, connecting the capital with other main cities throughout the Spanish peninsula territory. The daily average traffic intensity for these roads is over 100,000 vehicles/ day in most sections (Ministry of Public Works and Transport 2016), conforming the main passageways to and from the capital.

Simultaneously, there are three main concentric ring-roads to Madrid: M30 surrounding the urban core, M40 (with a radius of approximately $10 \mathrm{~km}$ ) connecting the closer periphery, and M50 (with a radius of approximately $15 \mathrm{~km}$ ) connecting the farther periphery and interrupted in its northern section by the protected area of El Pardo Mount. These ringroads act as 'proximity levels' to the urban centre and delimit the area of study for this work.

The criteria for the selection of the roads for this case study was also aimed to achieve a relatively homogeneous sample throughout the urban fringe, with many potential viewers:

- Main highways, with more than one lane in each direction

- Sections of the roads between the farthest ringroad (M50) and the city centre (M30 or beyond)

- Daily average traffic intensity over 100,000 vehicles/day in at least some part of the road section

\section{- Accessible to private cars at any time}

During fieldwork, the inbound sections of all six main access roads are covered by car from their intersection with the M50 ring-road (the farthest proximity level) until the $\mathrm{M} 30$ and sometimes beyond, entering the city core. By taking pictures from the car with a frame rate of 4 seconds, at an average speed of $90 \mathrm{~km} / \mathrm{h}$, we obtain a sequence of frames, approximately every $100 \mathrm{~m}$, throughout the entire path. As far as possible, rush hours were avoided; field trips were carried out during the mornings, between $10 \mathrm{am}$ and $1 \mathrm{pm}$, when it is less probable to find traffic congestion, which would alter the frame rate and impede visibility.
From the data collected during fieldwork, the most relevant frames for each road are selected (Fig. 7), distinguishing the 'level of proximity' of each frame: between the M50 and the M40, between the M40 and the $\mathrm{M} 30$, and from the $\mathrm{M} 30$ to the city centre. As in the deskwork for each lookout, the selection of relevant frames is followed by a series of interpretive drawings.
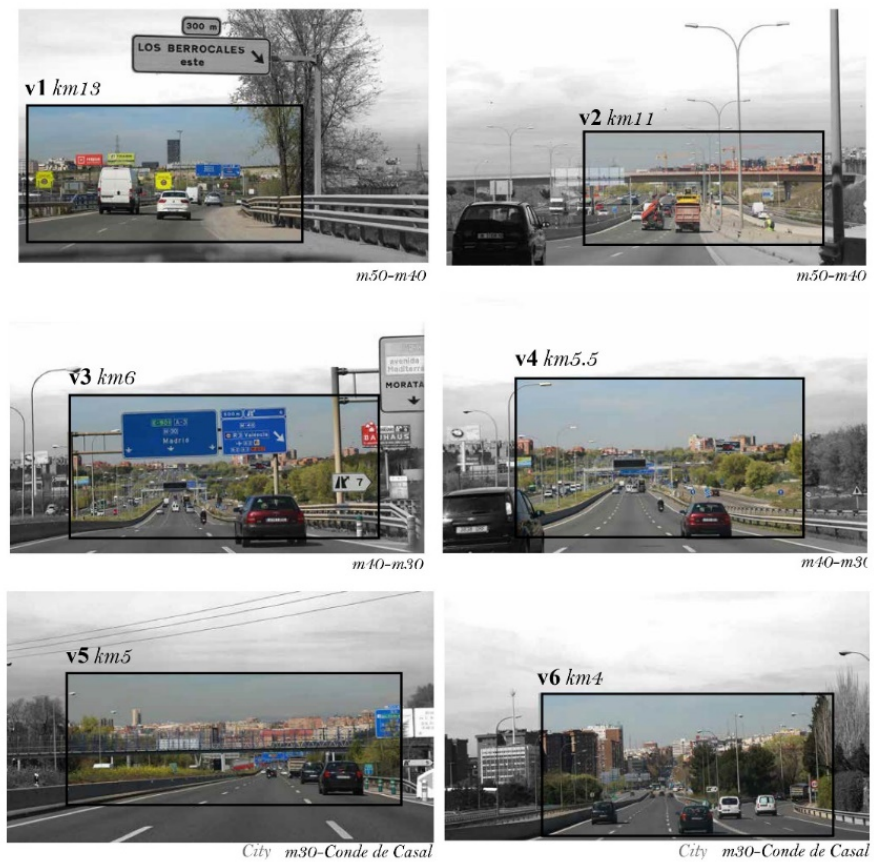

Figure 7: Selection of frames throughout the studied section of the A3 main access road.

\section{Results}

As stated in the previous section, a total of fifteen natural lookouts and six main access roads located in the peri-urban area of Madrid are analysed following the proposed methodology. For the purpose of this paper, the results for a selection of two cases per type of element (lookouts and roads) are now further developed, illustrating the different landscape characters this method can document and represent at a local scale.

\subsection{Temple of Debod' versus 'Tio Pio' lookouts}

'Temple of Debod' lookout, named after the Egyptian temple donated by the Egyptian Government in the 1970s, is located in a public park on the western entrance of the historic city core, inside the M30 
ring-road. The visual basin generated from the topographic model shows a predominant visibility towards the west and southwest city-countryside fringe. This is corroborated by the fieldwork, generating a 360 o panorama taken from the west axis of the temple, at an altitude of $645.32 \mathrm{~m}$ (Fig. 8).

Three frames are highlighted in the panorama, further analysed through interpretive drawings:

- L1, looking towards the countryside. Behind the abundant pinewood of Casa de Campo (a forest park protected by National Heritage), appears the industrial landscape of the southern district of Carabanchel. Surrounded by both evergreen and deciduous vegetation and scattered by factory towers, certain urban elements (such as the rollercoasters of the amusement park nearby) act as distinctive references in the view.

- L2, looking towards the city. This view shows some of the city's most recognizable twentiethcentury buildings, acting as landmarks over a base of evergreen vegetation and medium-size deciduous trees.

- L3, framing the city's historical 'cornice'. The silhouette shaped by the Royal Palace, La Almudena Cathedral, the domes of San Francisco el Grande Basilica and other churches and old parishes, as well as the rooftops of the traditional domestic architecture of Madrid.

'TíoPío' lookout, on the other hand, shows a whole different array of characteristics. Located farther from the historic city than the previous example, between the M30 and the M40 ring-roads, the view from this hill in the southeast landscape of Madrid opens to north, west and (especially) the southwest, as shown in the visual basin generated from the topographic model. Despite the topographic level in this area of the city being generally lower than in the northwest, the hill over which this particular lookout stands reaches $680.6 \mathrm{~m}$, making it one of the broadest and most effective viewpoints of this side of Madrid.

During the twentieth century, this area was part of a shanty, informal growth in between abundant cropland. The pre-existing substandard housing was demolished in the seventies, and the new constructions were not finished until the eighties, remaining today as one of the most predominant elements of the surroundings (Fig. 9).

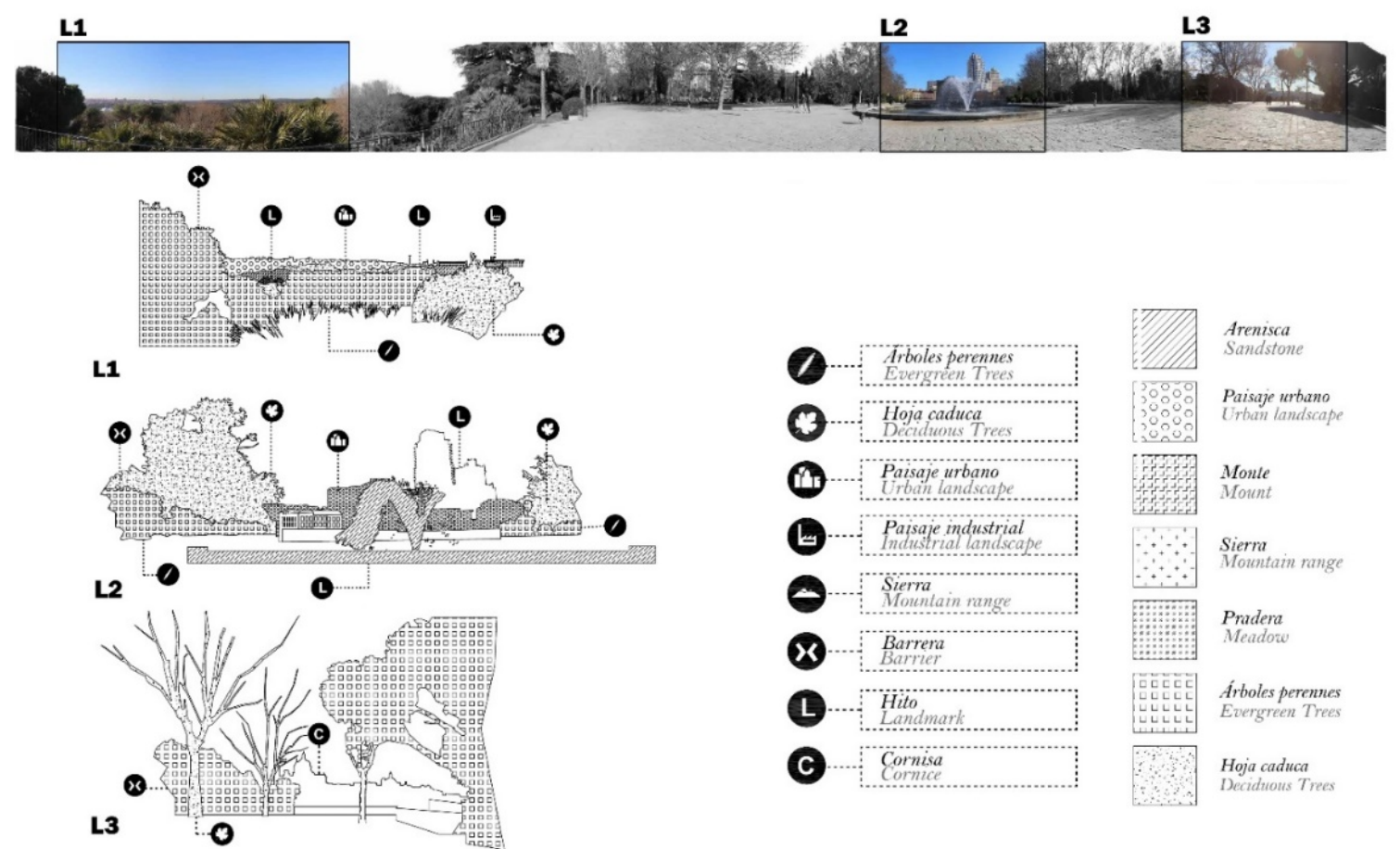

Figure 8: Panorama, selected frames and interpretive drawings from 'Temple of Debod' lookout. 


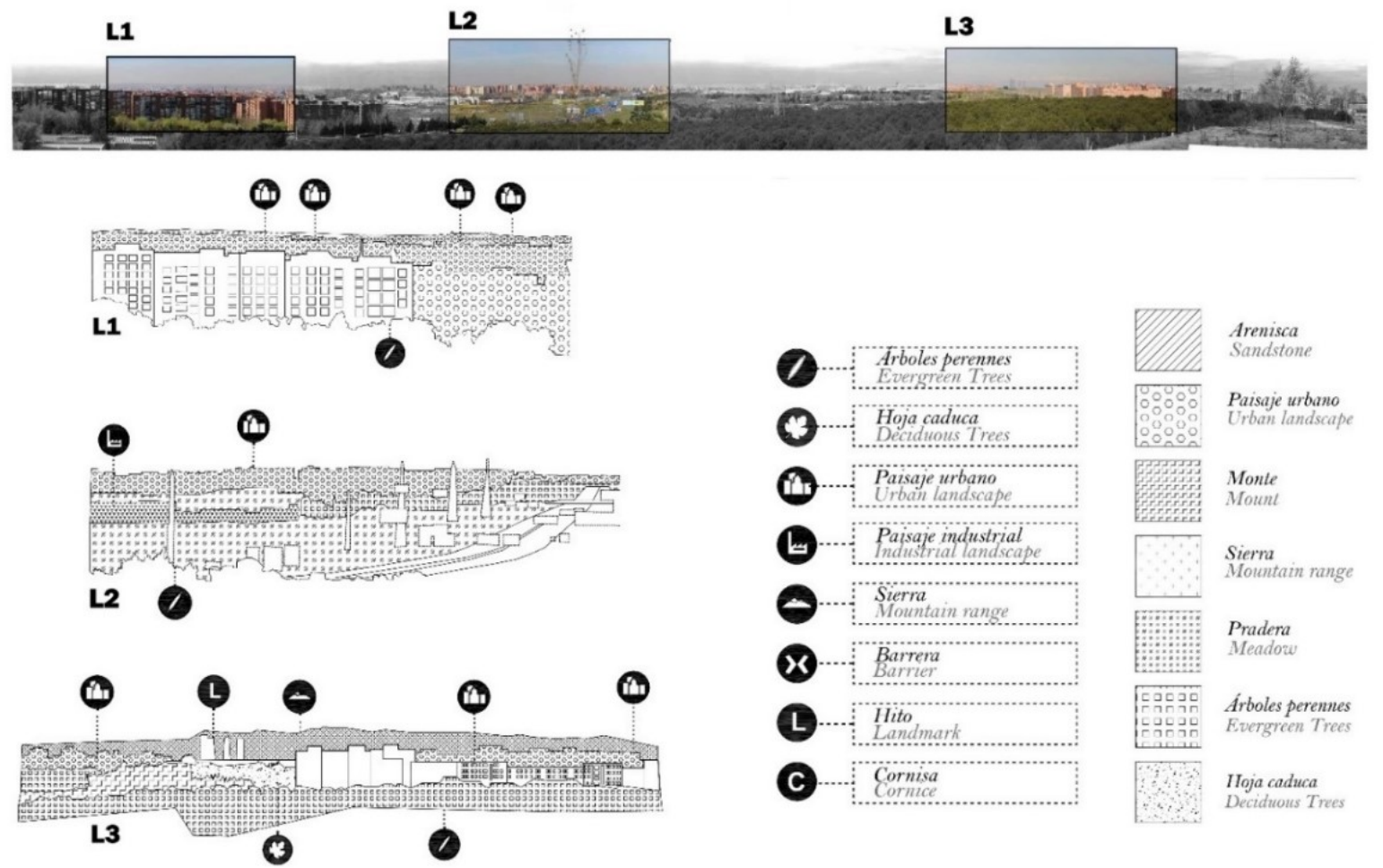

Figure 9: Panorama, selected frames and interpretive drawings from 'TíoPío' lookout.

As in the previous case, three frames are highlighted in the panorama, further analysed through interpretive drawings:

- L1, view to the east, showing much of the residential sprawl of the 1980 sin the surroundings.

- L2, framing a section of the A3 access road passing nearby, scattered with billboards and industrial warehouses to both sides.

- $\mathrm{L} 3$, towards the northern side of the city. Along with a fairly continuous urban mesh, we identify the four towers of the business areas; the most recognizable twenty-first century landmarks of Madrid. The mountain range is displayed in the background of the view, which overall shows a wide variety of vegetation, with large meadows in the sloped land. Pines, acacias and mulberry trees stand out, as well as jasmine and cotoneaster bushes.

The location of this second viewpoint, sufficiently distanced from the city centre, also provides a clear view of a 'brown cloud' of air pollution over the city, affecting how its skyline is perceived. This was not the case with the views from Temple of Debod lookout, located closer to the city centre.

\subsection{A6 versus $A 3$ access roads}

The A6 highway connects Madrid with La Coruña, in the northwest end of the Iberian Peninsula. Built in 1932 as an avenue over an old path leading towards the north-western mountain range, it was transformed into a highway in 1969 and currently holds the heaviest traffic of all main access roads, with the highest number of vehicles per day throughout its entire metropolitan section. The descending topography towards the city, with slight elevation changes throughout, allow for a broad cityscape to appear from several points, showing some of the most recognizable elements of the city (Fig. 10).

As mentioned in the methodology, a total of six photograms are selected from the sequence documented throughout; two for each 'proximity level' delimited by the main concentric ring-roads:

- V1 and V2, selected from the M50-M40 section. In these frames, the city can be appreciated as a whole, providing a recognizable skyline that, at this distance (between 15 and $10 \mathrm{~km}$ from the city centre), appears as a continuous and homogeneous shade. 
- V3 and V4, selected from the M40-M30 section. Throughout this section, certain elements can be pointed out independently, such as the four towers in V4. These towers, built between 2004 and 2009 with heights ranging between 224 and 249 meters, have become the new reference of the city from farther distances. This has perceptually elongated the scale of what is seen as the 'city centre', for they are located at its northern end, just inside the M30 ring-road; an area not considered to be such of a central location before the towers were built.

- V5 and V6, selected from the M30 to the city core. As we reach the city centre, after crossing the M30 beacon, the early-twentieth-century garden city layout of the University campus and Parque del Oeste (the first public park of the city, built in 1899) eases the transition to the more densified urban fabric that follows. A succession of landmarks, such as the $92 \mathrm{~m}$-high lookout tower or the triumphal arch of Moncloa conform the entrance to the main west-east axis crossing the city.
As a result of the topography and the green spaces surrounding this side of the city's contour, the views throughout this main access road overall present a strong degree of visibility and openness, reflected in the depth of the views from most of the documented frames and the few obstructing objects along the way.

In contrast, the view entering Madrid from the $\mathrm{A} 3$ road, which connects the capital with Valencia (in the east coast of the Iberian Peninsula), shows an overall lack of historical landmarks and green spaces. Unlike the case of the $A 6$, the topography of the $A 3$ slightly rises as we approach the city, descending only during the last $3 \mathrm{~km}$, reason for which the city is almost imperceptible throughout the whole analysed section. This highway displays and array of billboards, traffic signs and industrial warehouses scattered along its sides throughout its whole length; elements that not only define the character of the view but also act as barriers that often prevent the driver from grasping what little portions of the city centre the views have to offer in the background (Fig. 11).

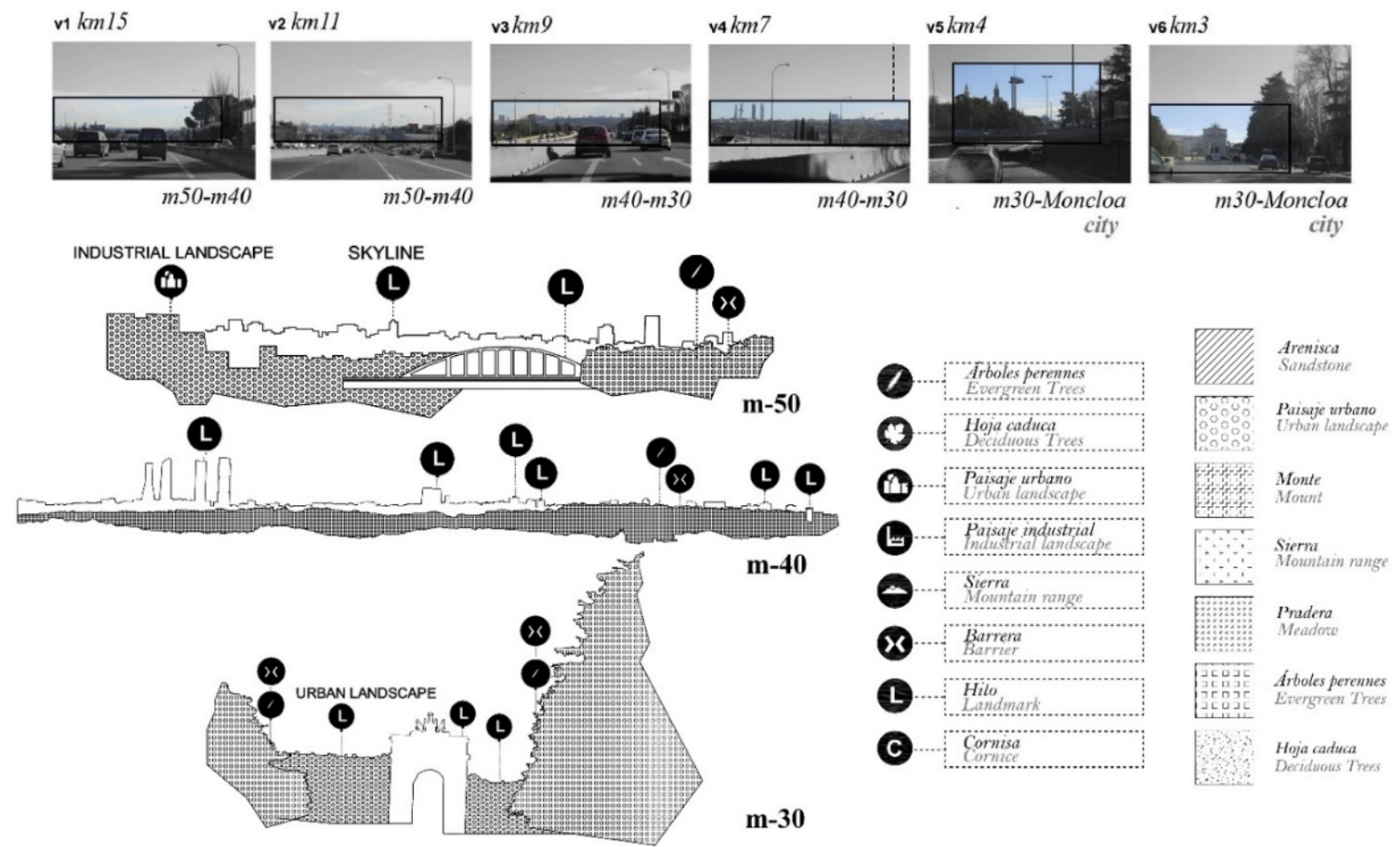

Figure 10: Selected frames and interpretive drawings from the analysis throughout the A6 road to Madrid. 


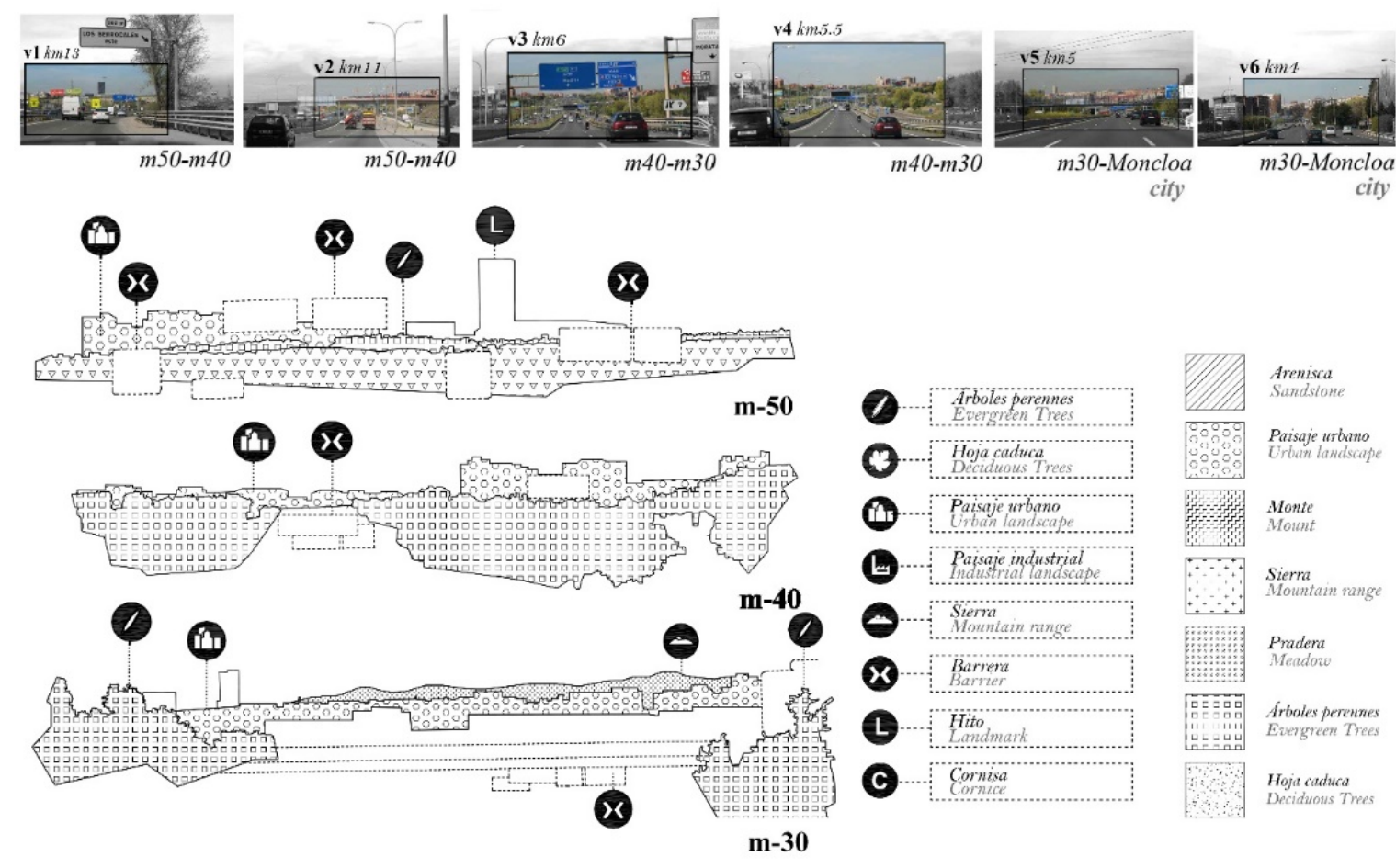

Figure 11: Selected frames and interpretive drawings from the analysis throughout the $A 3$ road to Madrid.

\section{Discussion}

This research has sought out to approach the periurban landscape of Madrid through the lens of two types of elements which, despite being universal and frequently found in peri-urban areas around many large cities, always have a particular effect and potential on those landscapes they are inserted in or traverse.

Fifteen natural lookouts and six main access roads located in the hinterland of the city of Madrid have been subject to the same method of analysis. This has allowed not only for the documentation of such a large territory, but has also brought to light the very different characters that, by comparison among cases, arise and help define landscape types from a visual and perceptive point of view. Therefore, the two main characters within the hinterland of the case study shown in this work are illustrated by the local approaches provided through the proposed method, leading towards a more informed and closely documented landscape characterization of the peri-urban surrounding of the city.
5.1 Feeding into a landscape analysis at a metropolitan scale: the northwest versus the southeast

The metropolitan area of Madrid has historically dealt with a strong contrast between the northwest and the southeast territory; a confronting nature in terms of topographic conditions, soil characteristics, vegetation and urban morphology, which has also translated into strong environmental and social inequalities between these two 'sides' of the city. While this issue has been subject to study from many disciplines, ranging from ecological (Environment and Territorial Planning Department 2007) to social and political points of view (Naredo \& Frías 2003, Hernández Aja et al. 2018, Observatorio Metropolitano 2007), it is also interesting to see (in the face of the results presented here) how this southwest-northeast 'diagonal', casted throughout time, indeed defines two very different landscape characters from a visual and perceptive dimension (Fig. 12); aspects that are often unattended or considered second to other more unequivocal economic-driven dynamics. 


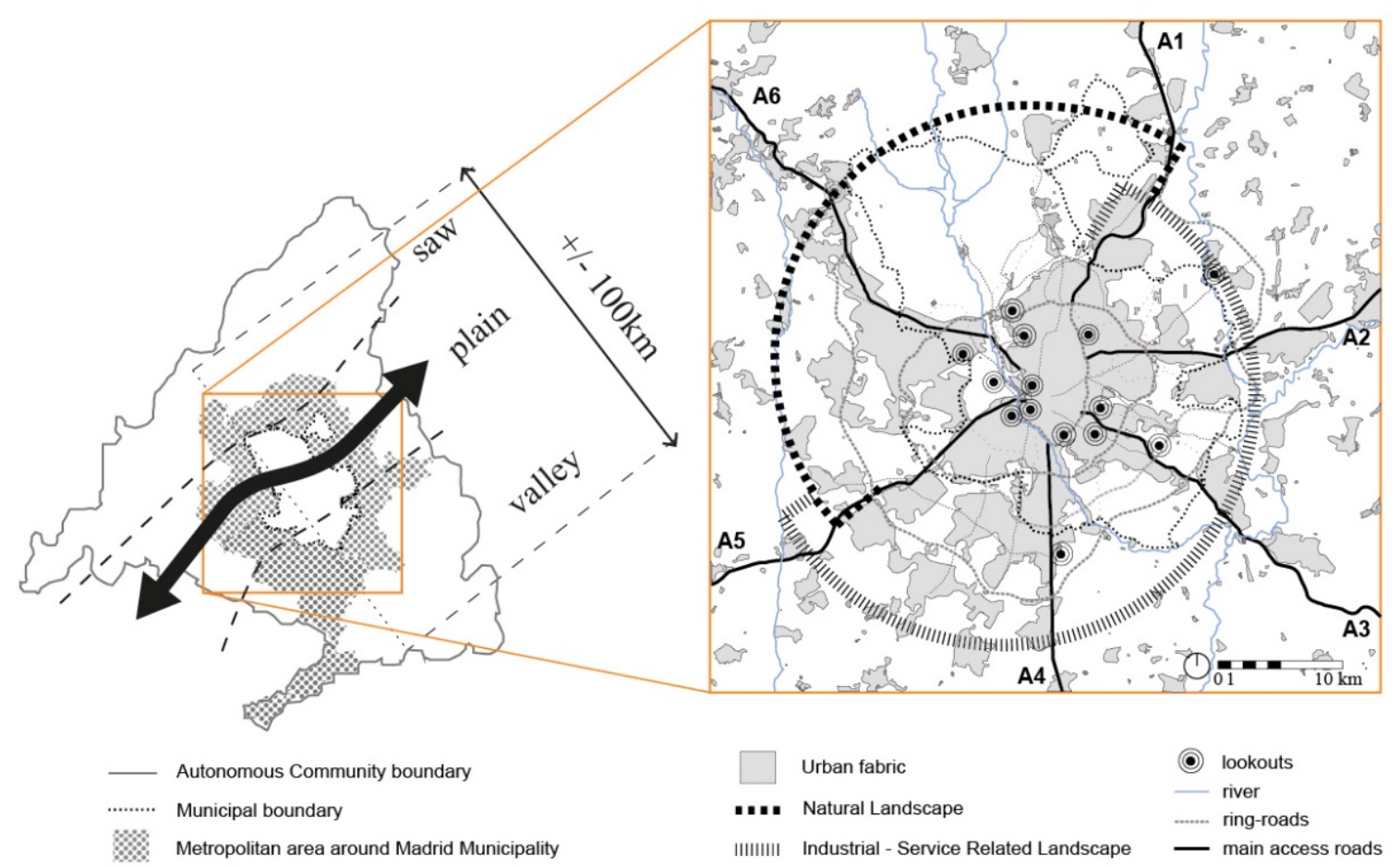

Figure 12: Southwest-northeast 'diagonal' dividing the main two landscape types in Madrid, at a regional scale (left) and at a metropolitan scale (right).

The landscape surrounding the northwest of the city is predominantly natural, due to the presence of mainly two protected areas, named 'Royal Places': El Pardo Mount to the north (a Mediterranean mount filled with holm oaks) and Casa de Campo to the south (area planted with Mediterranean pine wood). This greenery, as shown in the landscape analysis from the A6 access road (section 4.2), acts as a plinth of the cityscape, preserving some of its iconic views from a range of distances between six and ten kilometres.

Even though the three selected frames of the view from 'Temple of Debod' lookout (section 4.1) are significantly different from each other, there is an overall abundance of historical urban landmarks at a close and medium range, as well as large extensions of protected green space that allow for open and long-distance views towards the countryside. The main obstructions in the panoramic view are due to the placing of urban furniture (lighting, safety railings, planted trees in the park, water features...), nevertheless allowing for both 'historic' and 'natural' features to effectively present themselves in this western (though quite central) location within the urban fringe.
Corroborated by the rest of the lookouts located in the northwest area, there is a higher level of complexity and natural richness in this area when compared to the local approaches in the southeast area, with overall higher levels of disturbance and a lack of historic references, architectural landmarks or contextual fit and coherence. This is illustrated in the landscape documentation and analysis of the views throughout the previously described $A 3$ road, but is also corroborated with the same method applied to the $A 2$ and $A 4$ access roads, drawing a south-to-east arch where, despite particularities in each one, they share an overall similarly bland, dry and service-related landscape character.

The selected frames of the view from 'TíoPío' lookout also show somewhat different features between each other, however the predominant elements in the visible landscape are less recognizable or particular of the city of Madrid. The wide highway entering the city (with its associated elements, such as billboards and industrial premises), the predominant and homogeneous residential fabric, or the presence of a business centre with highrise towers in the distance are all typically shared features of peri-urban landscapes in Europe. The 
view from this lookout, highly valuable in terms of visibility and lack of obstructing elements, is also highly effective in illustrating the residential sprawl, mix of uses and large-scale infrastructures typically found in the southeast hinterland of Madrid.

The findings at a local scale presented in this work have shown strong potential to aid in the definition and qualification of different landscape types at a metropolitan scale. The application of the proposed method in the mentioned lookouts and roads corroborate, for the case of the peri-urban area of Madrid, the overall contrasting characters between its northwest and southeast landscapes. They also illustrate commonly shared aspects of peri-urban areas around most large European cities, such as landscape fragmentation, dispersion and heterogeneity (as defined in section 1.2).

\subsection{On the applicability of the method: limitations and opportunities}

Landscape is experienced in motion and continuity (Sheller \& Urry 2006); outstanding and everyday landscapes are interwoven in a continuous sequence, and the methods to document this experience should reflect said reality. In that sense, once the elements of study are selected according to certain criteria, 360 o views from the lookouts and systematic photographing throughout the roads provide an archive of data, free from preconceived ideas of worthiness of certain landscapes over others. This approach, supported by cartography and other physical indicators, seeks to unveil certain ordinary landscapes which have been side-lined in the past, documenting their current state and relation with the better-known, outstanding ones.

Landscape perception can be approached from very different standpoints; an 'expert' view, a 'non-expert' view, or a combination of both. Here it is worth noting that the use of the term 'expert' could also be questioned, given the innate 'expertise' that the local community, regardless of their previous training or education, show in relation to their ordinary surrounding (see Larrère \& Larrère 2009). While works with local communities have traditionally used photographs to effectively reach broader social groups (see, e.g., Van Auken et al. 2010, Milcu et al. 2014), assessing the reactions to (and reflections upon) certain images, we defend in this paper that this same exercise can be carried out in an 'expertbased' method such as the one presented here. Photography can not only help specialists in the field to document the landscape, but can also serve as a basis for further analysis and interpretation of landscape shapes, layers and dynamics (as done with the selection of relevant frames and generation of interpretive drawings).

In the expert-based method proposed here, the analysis and interpretation that followed the fieldwork consider perceptive factors such as the relation between landmarks, barriers, relative depths between planes, sturdiness, continuity, homogeneity or representativeness of both natural and anthropogenic landscape structures. Relevance was given to certain views and elements, always from the researchers' perspective. However, building on these findings, future work in this line would benefit greatly from inputs from a non-expert perspective (e.g. Riechers et al. 2017), combining a wider range of perspectives from different stakeholders, enabling further research in landscape preference and perception of local communities, and shedding much-needed light on complex issues such as symbolism and place attachment.

Natural lookouts have proven to be privileged sites from where to identify landscape patterns. The selection criteria for the lookouts has brought up a sample composed by both well-known observation points, strongly rooted in the cultural history, and somewhat anodyne sites which, nevertheless, provide extraordinary views of the city and its surrounding countryside. Their potential as witnesses of the evolution in the landscape could be further explored with historical analysis from each specific site, identifying the loss or permanence of certain key elements throughout time. Similar tools to the ones presented in this paper for the study of lookouts have been developed for the landscape characterization of urban cores in the region of Andalusia (Pardo 2010).

The study of the main access roads has shown an abundance of everyday landscapes and revealed the importance of differentiating 'levels of proximity' for the analysis of the views. For such distinction, the ring-roads acted as 'tipping points' along the path 
towards the city centre. Research on this typology could be extended to the opposite direction of travel, for landscape perception while exiting the city is as much of a reality for daily commuters as it is to enter it. In terms of representativeness, deciding to avoid rush hours to carry out the field work on the main access roads may seem incoherent with the idea of capturing the perception of most daily commuters, which would accumulate particularly during those hours. Though this could constitute a limitation of the research, a homogeneous frame rate and maximum visibility of landscape components throughout the roads for their documentation and analysis was considered the priority.

This research has addressed landscape perception at two very different speeds and means of transportation; walking for the lookouts, by car for the roads. However, it could be extended with data regarding other ways of approaching the city. For instance, introducing commuter cycling (Spinney 2009, Jones \& Burwood 2011) would be highly relevant; a means of transportation that is increasingly promoted by public institutions in large cities and expected to grow in the coming years.

From the findings presented, we can also deduce the relevance that the green peri-urban spaces have in the generation of a recognizable 'naturalistic' character, and the decisive role of protection mechanisms to preserve it in the face of urban regeneration or growth. In line with current trends of urban greening (Urbano 2013, Carrus et al. 2015), the tools presented in this paper can help assess the consistency between historical parks, urban promenades and new parks at a metropolitan scale; a quality that is considered essential to maintain the legibility of the landscape (Antrop 2005). Furthermore, changes throughout the year could be documented by applying the method in different seasons, illustrating the impact of 'ephemera' in visual landscape character; one of the key concepts described by Tveit, Ode and Fry (2006).

Overall, the outcomes of this method show its potential for monitoring landscape change, illustrating a multifaceted vision of the rural-tourban experience, which can become a useful tool in both the design and management of our lived environment. Strongly based on graphic tools, results of this qualitative approach can feed into a broader collection of data for a Landscape Character Assessment and supply decision-making agents from a range of disciplines (landscape architecture, planning, geography or environmental psychology) with useful information when tackling new urban designs.

By resorting to natural lookouts and roadscapes, two very common elements found in the periurban fringe of cities world-wide, this method is considered especially suitable for metropolitan areas, with the potential to address specific issues of peri-urban landscapes and ultimately improve the daily experience of an increasing number of people. The tools involved can be effectively applied in other cities and are versatile enough to fit the specific features and scale of each case study.

\section{Conclusions}

Sensibility towards landscape features and cityscapes is nothing new. However, the recent framework of the European Landscape Convention and emergence of concepts such as 'urban landscape' and 'historical urban landscape' (as a counterpoint to the 'generic city') has revealed the importance of incorporating landscape values into contemporary urban planning (Zoido 2002, Antrop 2005, Cruz \& Español 2009, Zárate 2011). Landscape Character Assessment has proved to be a useful tool for such endeavour, providing a solid evidence base linked to place (Tudor 2014) that combines factual statements with more subjective and evocative elements. The methodological approach presented here provides tools to tackle the study of landscape components at a local scale; an essential step (not only in character assessment) to understand how landscape is perceived and experienced.

The complex reality of the areas of influence around large cities calls for a closer look at the basic elements that conform them, and that link (visually, physically, logistically) the city with its daily commuting zone. Knowledge and sensibility towards these periurban landscapes, predicted to have a leading role in Europe's near future (Piorr et al. 2011), can contribute to the creation or preservation of spaces 
with identity, structure and meaning, the sum of which shapes an 'environmental image' (Lynch 1960), present today in the urban agendas of cities world-wide.

In this work, we resort to natural lookouts and roadscapes in the hinterland of Madrid to illustrate the systematic collection and generation of data at a local scale, bound to a gap of knowledge of the city at a metropolitan scale. Overcoming the conventional formats of displaying and analysing 'perceptive data', which is often relegated to mere descriptions and photographs, the cartography and vistas presented serve as 'active' documents that allow for further analysis and interpretation, revealing key aspects of the surrounding, and suggesting that findings at the local scale can shed light on larger-scale landscape questions.

\section{Acknowledgements}

This research has been part of the State Plan Project of the Spanish Ministry of Economy and Competitiveness (HAR2014-57843-R) entitled "Proximity landscapes of the city of Madrid. From the 19th century to the present" (2015-2018), and of the ongoing research project entitled "The periurban landscape of Madrid: views from the memory to the new city" funded by CEU-Banco Santander in its V Convocatoria de Ayudas a Proyectos Puente y Consolidación. We thank the Spanish Ministry of Education for the pre-doctoral scholarship (FPU14/05524) granted to co-author Carlota Sáenz de Tejada Granados in its FPU Program, and Universidad CEU San Pablo Foundation for the predoctoral scholarship granted to co-author Rocío Santo-Tomás Muro in its FPI Program.

\section{References}

Allen, A.; Da Silva, N.L. \& Corubolo, E. 1999. Environmental problems and opportunities of the peri-urban interface and their impact upon the poor. The Development Planning Unit, University College, London.
Allen, A. 2003. Environmental planning and management of the peri-urban interface: perspectives on an emerging field. Environment \& Urbanisation 15(1), 135-148. DOI: $10.1177 / 095624780301500103$

Antrop, M. 2000. Background concepts for integrated landscape analysis. Agriculture, Ecosystems \& Environment 77(1-2), 17-28. DOI: 10.1016/S0167-8809(99)00089-4

Antrop, M. 2005. Why landscapes of the past are important for the future. Landscape and Urban Planning 70(1-2), 21-34. DOI: 10.1016/j.landurbplan.2003.10.002

Appleton, J. 1975. The experience of landscape. Landscape Research 1(10), 15-16. DOI: $10.1080 / 01426397508705780$

Azagra Ros, J.; Mas Ivars, M. \& Goerlich Gisbert, F. 2006. La localización de la población española sobre el territorio. Un siglo de cambios: Un estudiobasadoen series homogéneas (19002001) (The location of Spanish population over the territory. A century of changes: A study based on homogeneous series (1900-2001)). Fundación BBVA, Bilbao.

Banham, R. 1971. Los Angeles. The Architecture of Four Ecologies. Allen Lane/ The Penguin Press, London.

Berger, A. 2006. Drosscape: Wasting Land in Urban America. Princeton Architectural Press, New York.

Carrus, G.; Scopelliti, M.; Lafortezza, R.; Colangelo, G.; Ferrini, F.; Salbitano, F. \& Sanesi, G. 2015. Go greener, feel better? The positive effects of biodiversity on the well-being of individuals visiting urban and peri-urban green areas. Landscape and Urban Planning 134(Supplement C), 221-228. DOI:10.1016/j.landurbplan.2014.10.022

de Certeau, M. 1980. L' invention du quotidien. Tome 1: Arts de faire. UGE, Paris. 
Chatel, C.; Morillas-Torne, M.; Marti-Henneberg, J., \& Esteve, A. 2017. Patterns of population and urban growth in southwest europe: 19202010. Journal of Urban History, 43(6), 1021. DOI: 10.1177/0096144217726974

City Council of Vancouver 2011. Land Use and Development Policies and Guidelines: View Protection Guidelines. http://vancouver.ca/docs/ planning/view-protection-guidelines.pdf (Date: 15.09.2017)

Coles, R.; Millman, Z. \& Flannigan, J. 2013. Urban landscapes - everyday environmental encounters, their meaning and importance for the individual. Urban Ecosystems 16(4), 819-839. DOI: $10.1007 / s 11252-013-0327-y$

Council of Europe. 2000. European Landscape Convention. Florence.

Cruz, L. \& Español, I. 2009. El paisaje. De la percepción a la gestión (Landscape. From perception to management). Enrahonar: An International Journal of Theoretical and Practical Reason (45), 179. DOI: 10.5565/rev/enrahonar.232

Cullen, G. 1971. The Concise Townscape. Van Nostrand, New York.

Davenport, M. A. \& Anderson, D. H. 2005. Getting from sense of place to place-based management: An interpretive investigation of place meanings and perceptions of landscape change. Society \& Natural Resources 18(7), 625-641. DOI:10.1080/08941920590959613

Daniel, T. C. 2001. Whither scenic beauty? visual landscape quality assessment in the 21st century. Landscape and Urban Planning 54(1), 267. DOI: 10.1016/S0169-2046(01)00141-4

Devine-Wright, P. 2013. Explaining "NIMBY" objections to a power line: The role of personal, place attachment and project-related factors. Environment and Behavior 45(6), 761-781. DOI:10.1177/0013916512440435
Environment and Territorial Planning Department 2007. Atlas. El Medio Ambiente en la Comunidad de Madrid (Atlas. The Environment in the Community of Madrid). Publica Madrid, Madrid.

Español Echániz, I. 2010. El paisaje como nuevo paradigma de la sostenibilidad, Fabrikart 9, 104115.

Eurostat 2016. Urban Europe: Statistics on Cities, Towns and Suburbs. Eurostat Statistical Books, European Union. Available in: http://ec.europa. eu/eurostat/documents/3217494/7596823/KS01-16-691-EN-N.pdf/0abf140c-ccc7-4a7f-b236682effcde10f (Date: 20.09.2017)

Gallardo, M., \& Martínez-Vega, J. 2016. Three decades of land-use changes in the region of Madrid and how they relate to territorial planning. European Planning Studies 24(5), 10161033. DOI:10.1080/09654313.2016.1139059

Greenbie, B. B. 1982. The landscape of social symbols, Landscape Research 7(3), 2-6. DOI:10.1080/01426398208706035

Hernández Aja, A.; Rodríguez Alonso, R.; Rodríguez Suáres, I.; Gómez Jiménez, J. M.; González García, I.; Córdoba Hernández, R.; Aguacil Gómez, J.; Camacho Gutiérrez, J.; Carmona Mateos, F. \& Jaramillo Cáceres, S. 2018. Barrios vulnerables de las grandes ciudades españolas 1991/2001/2011. Instituto Juan de Herrera, Madrid.

Hopper, D. 1961. Double Standard. The Dennis Hopper Trust, MoMA. https://www.moma.org/ collection/works/125271 (Date: 01.03.2018).

Jackson, J. B. 1984. Discovering the Vernacular Landscape. Yale University Press, New Haven and London.

Jackson, J. B. 2011. Las carreteras forman parte del paisaje (Roads are part of the landscape). Gustavo Gili, D. L., Barcelona. 
Jones, C. D.; Patterson, M. E., \& Hammitt, W. E. 2000. Evaluating the construct validity of sense of belonging as a measure of landscape perception. Journal of Leisure Research 32(4) DOI: 10.1080/00222216.2000.11949922

Jones, P. \& Burwood, D. 2011. Cycling and the City: Reflections of Commuting Practices, Liminalities: A Journal of Performance Studies 7(4). $\quad$ http://liminalities.net/7-4/cycling.pdf (Date: 21.01.2019).

Jones, P. \& Evans, J. 2012. Rescue geography: Place making, affect and regeneration. Urban Studies 49(11), 2315-2330. DOI:10.1177/0042098011428177

Jones, P.; Isakjee, A.; Jam, C.; Lorne, C. \& Warren, S. 2017. Urban landscapes and the atmosphere of place: Exploring subjective experience in the study of urban form. Urban Morphology 1(21), 29-40. http://www.urbanform.org/online_unlimited/ pdf2017/201721_29.pdf (Date: 14.02.2018)

Kagan, R. 1986. Philip II and the Art of the Cityscape, The Journal of Interdisciplinary History 17(1), 115135. DOI: $10.2307 / 204127$

Kaplan, S. \& Kaplan, R. 1978. Humanscape: Environments for People. North Scituate, Mass, Duxbury.

Kargon, J. 2014. One city's 'urban cosmography'. Planning Perspectives 29(1): 103-120. DOI: $10.1080 / 02665433.2013 .860880$

Larrère, C. \& Larrére, R. 2009. Du bon usage de la nature: Pour unephilosophie de l'environment. Flammarion, Paris.

Lynch, K. 1960. The image of the city. The MIT Press, Cambridge, Massachusetts.
Martí Marí, S. 2014. This is not land art paisajesconducidos (This is not land art_driven landscapes). Ausart Aldizkaria. Revista Para La Investigación En Arte 2(2), 161-174. https:// www.ehu.eus/ojs/index.php/ausart/article/ view/14015/12409 (Date: 25.09.2018)

Merriman, P. 2008. Driving Spaces: A Cultural - Historical Geography of England's M1 Motorway. Blackwell Publishing Ltd. DOI:10.1002/9780470762448

Merriman, P. 2009. Automobility and the Geographies of the Car. Geography Compass 3: 586-599. DOI:10.1111/j.1749-8198.2009.00219.x

Milcu, A. I.; Sherren, K.; Hanspach, J.; Abson, D., \& Fischer, J. 2014. Navigating conflicting landscape aspirations: Application of a photobased Q-method in transylvania (central Romania). Land Use Policy 41, 408-422. DOI: 10.1016/j.landusepol.2014.06.019

Naredo, J. M. \& Frías, J. 2003. El metabolismo económico de la conurbación madrileña. 19842001, Economía Industrial, 351(3), 97-114. https://www.mincotur.gob.es/Publicaciones/ Publicacionesperiodicas/Economialndustrial/ RevistaEconomialndustrial/351/Economia06.pdf (Date: 24.10.2018)

Negussie, E. \& Fernández, V. 2013. Impact of the Cajasol (Pelli) Tower on the skyline of Seville. CIVVIH Newsletter 20, 15-16.

Observatorio Metropolitano 2007. Madrid: ¿la suma de todos? Globalización, territorio, desigualdad. Traficantes de Sueños, Madrid.

Ode, A.; Fry, G.; Tveit, M. S.; Messager, P. \& Miller, D. 2009. Indicators of perceived naturalness as drivers of landscape preference, Journal of Environmental Management 90(1), 375-383. DOI: 10.1016/j.jenvman.2007.10.013 
OECD Territorial Development Policy Committee 2013. Definition of Functional Urban Areas (FUA) for the OECD metropolitan database. https:// www.oecd.org/cfe/regional-policy/Definitionof-Functional-Urban-Areas-for-the-OECDmetropolitan-database.pdf (Date: 11.11.2017)

Palang, H.; Spek, T. \& Stenseke, M. 2011. Digging in the past: New conceptual models in landscape history and their relevance in peri-urban landscapes. Landscape and Urban Planning 100(4), 344. DOI: 10.1016/j.landurbplan.2011.01.012

Pardo García, S. M. 2010. Aproximación metodológica a las vistas de los núcleos de población: El caso de Vélez-Málaga ). Cuadernos Geográficos De La Universidad De Granada (46), 35. http:// revistaseug.ugr.es/index.php/cuadgeo/article/ view/630/717 (Date: 10.02.2019)

Piorr, A.; Ravetz J. \& Tosics, I. 2011. Peri-urbanisation in Europe: Towards a European Policy to sustain Urban-Rural Futures (pp. 144) Academic Books Life Sciences University of Copenhagen, Copenhagen.

Planning Committee of Edinburgh. 2008. Skyline Report: The Protection of Key Views, The city of Edinburgh Council. http://www.edinburgh.gov. uk/info/20065/conservation/249/the_skyline_ study (Date: 17.11.2017)

Qviström, M. \& Saltzman, K. 2006. Exploring landscape dynamics at the edge of the city: Spatial plans and everyday places at the inner urban fringe of Mälmo, Sweden. Landscape Research 31(1), 21-41. DOI: 10.1080/01426390500448534

Qviström,M.2010.Shadowsofplanning:onlandscape/ planning history and inherited landscape ambiguities at the urban fringe. Geografiska Annaler, Series B: Human Geography 92(3), 219235. DOI: 10.1111/j.1468-0467.2010.00349.x

Riechers, M., Noack, E. M. \& Tscharntke, T. 2017. Experts' versus laypersons' perception of urban cultural exosystem services. Urban Ecosystems 20(3): 715-727. DOI: 10.1007/s11252-016-0616-3
Rodríguez Romero, E. J. \& Sáenz De Tejada Granados, C. 2017. Entre la ciudad y el campo. Evolución de la forma urbana en el noroeste de Madrid (Between city and countryside. Evolution of the urban form in the northwest of Madrid).Forma urbana: pasado, presente y perspectivasActas del I Congreso ISUF-H (Urban form: past, present and perspectives Proceedings of I Hispanic International Seminar of Urban Form), 626 - 633. DOI: 10.18239/jor_12.2017.04

Sanz Herráiz, C. \& Mata Olmo, R. 2010. Atlas de los paisajes de España (Atlas of Spanish landscapes). Ministerio de Medio Ambiente Centro de Publicaciones, Madrid.

Serrano Giné, D. 2015. Valoración escénica de paisaje periurbano con utilidad en planeamiento territorial. Estudio de caso en la Región Metropolitana de Barcelona. Investigaciones Geográficas 88, 109-121. DOI: 10.14350/rig.45090

Serrano Giné, D. 2018. A Renewed Approach to the $A B C$ Landscape Assessment Method: An Application to Muntanyesd'Ordal, Barcelona Metropolitan Area. Landscape Online 56, 1-13. DOI: 10.3097/LO.201856

Sheller, M. \& Urry, J. 2006. The new mobilities paradigm. Environment and Planning 38(2), 207226. DOI: $10.1068 / a 37268$

Simms, A.; Kjell, P. \& Potts, R. 2005. Clone town Britain: The survey results on the bland state of the nation. New Economics Foundation, London.

Smithson, R. 1967. Monuments of Passaic, James Cohan Gallery. https://www.robertsmithson.com /photoworks/monument-passaic_300.htm (Date: 28.02.2019).

Spanish Statistical Office. 2017. Banco de datos municipal de la Comunidad de Madrid (Municipal databaseoftheCommunityof Madrid). http:// www.madrid.org/desvan/almudena/run/j/Inicio. icm?enlace $=$ almudena (Date: 02.11.2017) 
Spinney, J. 2009. Cycling the city: Movement, meaning and method. Geography Compass 3(2), 817-835. DOI:10.1111/j.1749-8198.2008.00211.x

Thrift, N. 2004. Driving the city. Theory, Culture \& Society 21(4-5), 337-340. DOI: $10.1177 / 0263276404046060$

Tudor, C. 2014. An Approach to Landscape Character Assessment. Natural England, Government of the UK.

Tveit, M.; Ode, A. \& Fry, G. 2006. Key concepts in a framework for analysing visual landscape character, Landscape Research 31(3), 229-255. DOI: 10.1080/01426390600783269

United Nations General Assembly 2016. New Urban Agenda. Draft outcome document, United Nations Conference on Housing and Sustainable Urban Development (Habitat III). http://unipdcentrodirittiumani.it/public/docs/Habitat_III_ New_Urban_Agenda_10_September_2016.pdf (Date: 15.10.2017)

Urban Planning and Housing Area 2009. Plan de Calidad del Paisaje Urbano de Madrid (Plan for the Quality of Urban Landscape). Publicaciones Vivienda y Urbanismo, Madrid.

Urbano López, B. 2013. Naturación urbana, un desafío a la urbanización (Urban greening, a challengeforurbanization) Chapingo, serie Ciencias Forestales y del Ambiente 19, 225-236. DOI: 10.5154/r.chscfa.2013.01.004

Van Auken, P. M.; Frisvoll, S.J. \& Stewart, S. I. 2010. Visualising community: Using participantdriven photo-elicitation for research and application, Local Environment 15(4), 373-388. DOI: 10.1080/13549831003677670\#
Van der Horst, D. \& Lozada-Ellison, L.M. 2010. Conflictos entre las energías renovables y el paisaje: siete mitos y la propuesta de manejo adaptativo y colaborativo (Conflicts between renewable energies and landscape: seven myths and the proposal fora daptive and collaborative management),Nimbus 25-26, 231-251.

Venturi, R.; Brown, D. S., \& Izenour, S. 1977. Learning from Las Vegas: The Forgotten Symbolism of architectural form. The MIT Press, Cambridge, Massachusetts - London.

Wagstaff, D. J. 1966. Talking with Tony Smith, Artforum.https://www.artforum.com/ print/196610/talking-with-tony-smith-36795 (Date: 13.03.2019).

Wester-Herber, M.2004. Review:Underlying concerns in land-use conflicts - the role of place-identity in risk perception. Environmental Science and Policy 7(2), 109-116. DOI: 10.1016/j.envsci.2003.12.001

Zárate, M. A. 2011. Paisajes culturales urbanos, entre la protección y la destrucción (Cultural Urban Landscapes, betweenprotection and destruction). Boletín de la Asociación de Geógrafos Españoles 57,175-194.

Zoido Naranjo, F. 2002. El paisaje y su utilidad para la ordenación del territorio (Landscape and its usefulness in territorial planning). Paisaje $y$ Ordenación Del Territorio, 21-32.

Zube, E. H. \& Pitt, D. G. 1981. Cross-cultural perceptions of scenic and heritage landscapes. Landscape Planning 8(1), 69-87. DOI: 10.1016/0304-3924(81)90041-1

Zube, E. H.; Sell, J. L., \& Taylor, J. G. 1982. Landscape perception: Research, application and theory. Landscape Planning 9(1), 1-33. DOI: 10.1016/0304-3924(82)90009-0 